\title{
Phenotypic Correlation Between Egg Weight and Egg Linear Measurements of the French Broiler Guinea Fowl Raised in the Humid Zone of Nigeria
}

\author{
Dzungwe JT, Gwaza DS* and Egahi Jo \\ Department of Animal Breeding and Physiology, University of Agriculture, Makurdi, Nigeria
}

Received: 阱 September 27, 2018; Published: 眥 October 4, 2018

*Corresponding author: Gwaza DS, Department of Animal Breeding and Physiology, University of Agriculture, Makurdi, Nigeria

\begin{abstract}
This study was carried out in Funtua, Kastina State. A total of 119 Eggs of the French broiler guinea fowl were sourced at Songhai Agricultural center Funtua, Kastina State. The eggs were measured for egg linear measurements and egg length and egg width. Data obtained was subjected to statistical package for analysis [1]. The correlations between body weight and body linear measurements were determined using pearsons product moment correlation coefficient ( $\mathrm{r}$ ). Phenotypic correlation between egg weight and egg linear measurements was also determined. Egg weight had positive and significant $(\mathrm{P}<0.05)$ correlation with egg length $(0.275)$ and egg width (0.496). The correlation between egg shell index was negative (-0.058). The result shows that Egg weight can be improved by selection for egg length and width French broiler guinea fowl populations.
\end{abstract}

Keywords: Broiler-Guinea-Fowl; Correlation; Egg Linear Measurement; Egg-Weight

\section{Introduction}

Meat and meat products are major sources of high-quality protein and their amino acid composition usually compensates for deficiencies in the staple foods. Production of family poultry is regarded as an alternative way to alleviate poverty and support to ensure food security for socio-economically disadvantaged rural households (Branckaert and Gue'ye, 1999). In third world countries, the guinea fowl production could become much more valuable than it is today (Siana, 2005; Fajmilehin, 2010; Moreki, 2010). It thrives under semi intensive and extensive conditions, forages well, and requires little attention from the farmer (Dahauda, 2007). The guinea fowl also retains many of its wild ancestor's characteristics, they are hardy and resistant to environmental challenges, produces well in cool and hot conditions (Dahauda, 2007). Compared to chickens, guinea fowls are economically more suitable to tropical regions because of their adaptations to traditional breeding systems (Dahauda, 2007). The potential of the Guinea fowl to increase meat and egg production among low income farmers requires greater attention (Rhissa and Bleich, 2009). Guinea fowls are widely known in Africa (Solomon, 2012) and occur in few areas in Asia and Latin America. Strains newly created for egg and meat production in Europe, notably French broiler and layer guinea fowls show excellent characteristics for industrial scale production [2]. Guinea fowl production as a meat bird has proven to be a viable and profitable enterprise, thus providing opportunity for commercial production in many parts of the globe [2]. A survey indicated that interest in guinea fowl as an alternative poultry and specialty meat bird in the United States appears to be increasing. The French variety of guinea fowl is raised primarily for meat [2]. Although their growth rate is slower than that of broiler chickens, the carcass yield of male and female guinea broilers at 12 weeks of age is about 76.8 and 76.9\%, respectively (Hughes and Jones, 1980). In recent studies evaluating the optimum Crude Protein (CP) and Metabolic Energy (ME) for the French guinea fowl broiler, Nahashon (2005) reported carcass yields of about $70 \%$ at 8 weeks of age. Genetic and phenotypic correlations are useful in prediction of direct and indirect responses to selection and determination of optimum weight and expected correlated response to selection [3].

The external and internal egg quality traits are significant in poultry breeding, especially for their reproduction of future generations, breeding performance, quality and growth trait of chicks [4]. Egg quality traits determine price directly in commercial flocks and it is usually described in connection with consumer's 
right requirements [5]. In meat lines, the productivity and quality of the egg has been reported as an important factor for economic breeding and propagation flock [6]. Egg weight, shell thickness, weight of egg yolk and albumen are important egg traits influencing egg quality when other management conditions and fertility are not limiting factors [7]. Egg quality characteristics are influenced by many factors including genetic, maternal and environmental ones [8]. Genetic differences in egg quality characteristics have been reported to exist between species and between breeds, strains and families within lines $[9,10]$ had reported the possibility of determining some external egg quality traits from egg weight of pharaoh (Black variety) quail. It has also been reported that genetic improvement of correlated traits can be achieved by selection for one of the correlated traits [11] especially if one of the correlation traits has low heritability estimates [12]. The objective of this study was to evaluate the phenotypic correlations between egg weight and egg linear measurements of the French broiler guinea fowl in Nigeria with the intension that this relationship can be exploited for genetic improvement through correlated response to selection.

\section{Materials and Methods}

\section{Location of Study}

The study was conducted at Funtua in Kastina State. Funtua Local Government Area of Kastina State of Nigeria lies on latitude $11^{\circ} 32^{\prime \prime} \mathrm{N}$ and longitude $7^{\circ} 19^{\prime \prime} \mathrm{N}$, the area is warm with an average temperature of $32^{\circ} \mathrm{C}$ and a relative humidity of $44 \%$. It has a tropical climate with an average annual temperature of $24.8^{\circ} \mathrm{C}$ and rainfall of $1024 \mathrm{~mm}$ with the highest precipitation averaging $277 \mathrm{~mm}$ in August and no precipitation in January $(0 \mathrm{~mm})$. Its warmest month of the year was May with an average temperature of $29.2^{\circ} \mathrm{C}$ and the lowest temperature occurring in January $\left(21.9^{\circ} \mathrm{C}\right)$. The difference in precipitation between the driest and warmest months was $277 \mathrm{~mm}$. Variations in temperatures throughout the year was $7.3^{\circ} \mathrm{C}$.

\section{Experimental Design and Procedure}

The experimental design used was the completely randomized design (CRD). Eggs of the French broiler guinea fowl strain were sourced at Songhai Agricultural Research Centre, Funtua Katsina State of Nigeria. Parent stock birds from which eggs were collected were raised extensively on free range, feeds were supplemented with grains (maize, millet or wheat) and no medications provided. The French broiler guinea fowl eggs were selected based on visual observation of size, shape, color, cleanliness and uniformity.

\section{Parameters that were measured and data collection}

Parameters that were measured include egg linear traits, egg weight, egg shape index. Egg linear parameters were measured with the aid of a Vernier caliper. Egg length was measured by placing the egg vertically between the outer dimension jaws of the Vernier caliper, which were moved together until they secured the egg. The screw clamp was tightened to ensure that the reading did not change while the scale was being read and recorded. Egg width was measured by placing the egg horizontally between the outer dimension jaws of the Vernier caliper, which were moved together until they secured the egg. The screw clamp was tightened to ensure that the reading did not change while the scale was being read and recorded. Egg weights were taken using an electronic digital weighing scale in grams and recorded (Salter mix and measure electronic cooks scale). Egg shell index obtained as a ratio of the egg width and the egg length using the formula derived by Reddy (1979).

$$
\text { EggshellIndex }=\frac{\text { Averagewidthofegg }}{\text { Averagelengthofegg }} \times 100 \text { (Reddy et al. 1979) }
$$

\section{Data Analysis}

Data was collected on egg weight and egg linear measurements. Data collected was subjected to statistical package [1] for analysis of quantitative data to generate descriptive statistics for desired parameters, the correlations analyses was also done using pearsons product moment correlation coefficient (r) to determine the relationship between egg weight and egg linear measurements.

\section{Results}

\section{Egg Weight and Egg Linear Characteristics of The French Broiler Guinea Fowl}

Table 1 shows that the French broiler guinea fowl egg weight ranged from $36 \mathrm{~g}$ to $48 \mathrm{~g}$ with an average egg weight of $40.37 \pm 0.32$ g, egg length ranged from $4.55 \mathrm{~cm}$ to $5.95 \mathrm{~cm}$ with average egg length of $4.86 \pm 0.32 \mathrm{~cm}$, egg width ranged from $3.00 \mathrm{~cm}$ to $4.10 \mathrm{~cm}$ with an average egg width of $3.90 \pm 0.02 \mathrm{~cm}$ and egg shell index of the French broiler guinea fowls was $78.94 \pm 1.18$ which ranged from 7.78 to 86.00 .

Table 1: Mean Egg Weight and Egg Linear Measurement of the French Broiler Guinea Fowl.

\begin{tabular}{|c|c|c|c|}
\hline Parameter & Mean \pm SE & $\begin{array}{c}\text { Range } \\
\text { Minimum }\end{array}$ & Maximum \\
\hline Egg weight (g) & $40.37 \pm 0.32$ & 36.00 & 48.00 \\
\hline Egg length (cm) & $4.86 \pm 0.02$ & 4.55 & 5.95 \\
\hline Egg width (cm) & $3.90 \pm 0.02$ & 3.00 & 4.10 \\
\hline Egg shape index & $78.94 \pm 1.18$ & 77.8 & 86.00 \\
\hline
\end{tabular}

\section{Correlation Between Egg Weight and Egg Linear Measurements of The French Broiler Guinea Fowl}

The correlation between egg weight and egg linear measurements is presented in Table 2 Egg weight has a significant $(\mathrm{P}<0.01)$ positive correlation with egg length and egg width, a negative correlation with egg shell index. Egg length has a significant $(\mathrm{P}<0.01)$ positive correlation with egg width, negative correlation with egg shell index. Egg width has significant $(\mathrm{P}<0.01)$ positive correlation with egg weight, positive correlation with egg 
length and egg shell index. Egg shell index was negatively correlated with egg width, significantly $(\mathrm{P}<0.01)$ negative correlated with egg length and a positive correlation with egg width.

Table 2: Correlation between Egg Weight and Egg Linear Measurement of the French Broiler Guinea Fowl.

\begin{tabular}{|c|c|c|c|c|}
\hline Parameter & E wt & El & E wd & Si \\
\hline E wt $(\mathrm{g})$ & - & & & \\
\hline El $(\mathrm{cm})$ & $0.275^{* *}$ & - & & \\
\hline E wd $(\mathrm{cm})$ & $0.496^{* *}$ & 0.073 & - & \\
\hline $\mathrm{Si}$ & -0.058 & $-0.382^{* *}$ & 0.031 & - \\
\hline
\end{tabular}

\section{Discussion}

\section{Mean Egg Weight and Egg Linear Measurement of The French Broiler Guinea Fowl}

Variations in egg weight, egg length and egg width observed in this study have also been reported by different researchers [13] observed variations on egg weight and egg length of French broiler and domestic polish guinea fowls raised in the temperate region. [14] reported variations in egg weight, egg length and egg width of Fulani ecotype chicken; [15] also reported variations in egg length, egg width and egg diameter in Fulani and $\mathrm{T}_{\text {iv }}$ local chicken ecotype. These variations may be due to the inherent differences between the genetic influence of dams, sires and environmental dissimilarities. Egg size is usually related with body weight of laying hens [16]. In this study, the egg weight of the French broiler guinea fowl strain ranged from $36 \mathrm{~g}$ to $48 \mathrm{~g}$ while the mean weight was $40.37 \pm 0.32$ g. The value was lower than the mean weight (55.3 g) for French broiler guinea fowl and similar (40.7g) for domestic polish guinea fowl raised in the temperate region reported by $[13,16]$ reported lower mean values of $37.67 \pm 0.2 \mathrm{~g}$ and $37.91 \pm 0.39 \mathrm{~g}$ for pearl and black strains of guinea fowls respectively. However, [17] reported a similar range of between $38 \mathrm{~g}$ to $45 \mathrm{~g}$ for indigenous guinea fowl in Nigeria $[2,18,19]$. Also reported similar values to the value reported in this research. The differences observed in this study may be attributed to the different breeds and the different plane of nutrition in the population; also, differences in environmental factors such as uncontrolled mating of the French broiler guinea fowl with the indigenous guinea fowl on free range which must have led to the loss in vigor of the French broiler guinea fowl.

Mean egg length value $4.86 \pm 0.02 \mathrm{~cm}$ was lower than the value $(52.3 \pm 0.06 \mathrm{~cm})$ reported by [20]. Mean egg width value $(3.90 \pm 0.02$ $\mathrm{cm})$ was lower than the value $(4.49 \pm 0.03 \mathrm{~cm})$ reported by [20]. The value for egg shape index reported in this study $(78.94 \pm 1.18)$ was close to the value reported by Dudusola [21] for guinea fowl in Nigeria. Nowaczewsky [13] reported lower values of $73.7 \mathrm{~cm}$ and $74.4 \mathrm{~cm}$ for French broiler guinea fowl and polish domestic strains guinea fowl which did not differ significantly. The differences observed may be due to the differences in breeds, nutrition and management practices. The value for egg shape index observed in this study suggests that eggs are less prone to breakage and can make good for hatchability.

\section{Correlation Between Egg Weight and Egg Linear Measurements}

The correlation between egg weight and, egg length and egg width were moderately positive and significant $(\mathrm{P}<0.01)$. This implies that as egg weight increases, egg length and egg width also increase. The positive correlations observed in this study between egg weight and, egg length and egg width agree with the results of $[22,23]$. The relationship between egg length and egg width was low and positive. There was an inverse association between egg length and egg shape index. The reason for this relationship is the fact that egg length is the denominating factor in estimating shape index according to Panda [24,25]. This report agrees with reports of Cloprakan [26]. Egg width showed positive correlation with egg shape index. This is because egg shape index is directly related to egg width. The reason could be as a result of the denser part of the yolk occupying the width area which translates to heavier weight of the egg. This result is similar to results by [27-30] who reported positive correlation between egg weight and egg length.

\section{Conclusion}

Egg weight had positive correlation with egg weight and length. Genetic improvement of egg weight can be achieved by selection for egg length and width.

\section{Recommendation}

Genetic improvement program for egg weight in the broiler guinea fowl populations in Nigeria can be achieved by selection for egg width and length.

\section{References}

1. Minitab (2003) Minitab statistical software, release 14 for Windows. State college, PA, USA.

2. Nowaczewski VG, Witiewics M, Fratczak H kontecka A, ans Rosinski A (2008) Quality of eggs for domestic and French guinea fowl. Nuaka przyroda Technologia 2(2)

3. Hassan WA, Buvanendran V, Dim NI, Asinowo OA, Abubaka BY (1991) Genetic and phenotypic correlations for body weight in Yankasa sheep. Nigerian journal of Animal Production 18(1): 12-18.

4. Islam MA, Nashibori M (2001) Indegenous and naked neck chicken: a valuable genetic resource for Bangladish. Worlds Poultry Science Journal 65(1): 125-138.

5. Ukwu HO, Ezihe CO, Asaa SK, Anyogo ME (2017) Effect of egg weight on external and internal egg quality traits of Isa Brown egg layer chickens in Nigeria. Journal of Animal Science and Veterinary Medicine 2: 126-132.

6. Kumaril P, Gupta BR, Prakash BG, Reddy MRA (2008) A study of egg quality traits in Japanese quails. Journal of Vertenary and Animal Sciences 4 (6):227-231.

7. Khurshid A, Faroog M Durani, FR, Sarbiland K, Chand N (2003) Predicting egg weight, shell thickness and hatching weight of Japanese quails using various egg traits as regressors. International Journal of Poult Sci 2(2): 162-167. 
8. Bednarczyk M (1991) Eggs technology. Wud Nauk Tech Warszawa (in Polish).

9. Buss EJ (1982) Genetic differences in avian egg shell formation. Poultry Science 61: 2048-2055.

10. Ojedapo L O (2013) Phenotypic correlation between the external and internal quality traits of pharaoh quail rearedin derived savanna zone of Nigeria. Journal of Biology, Agriculture and Healthcare 3(10).

11. Gwaza DS, Igbayima WM (2015a) The use of Morphological Measurements for Charactrisation of Local Chicken Ecotype Populations. J Anim Prod Res 27: 21-26.

12. Gwaza DS, Ejeh MO (2015b) Assessment of within ecotype genetic divergence of the Yoruba local chickens in selected populations. Academia Journal of Biotechnology 3(5): 079-084.

13. Nowaczewski VG, Witiewics M, Fratczak H kontecka A, ans Rosinski A (2008) Quality of eggs for domestic and French guinea fowl. Nuaka przyroda Technologia 2(2).

14. Fayeye TR, Adeshiyan AB, Olugbemi A A (2005) Egg traits, hatchability and early performance of the Fulani ecotype chicken. Livestock Research for Rural Development 19(94).

15. Gwaza DS (2013) Genetic study of Fulani and $T_{\text {iv }}$ local chicken ecotype in the southern guinea savannah of Nigeria.

16. Obike O M, Oke U K, Azu KE (2011) Comparison of egg production performance and egg quality traits of pearl and black strains of guinea fowl in humid rain-forest zone of Nigeria. International Journal of poultry Science 10(7): 547-551.

17. Ayorinde KL, Ayeni JSO, Oluyemi JA (1989) Laying characteristics and reproductive performance of four indigenous helmeted guinea fowl varieties (Numidia meleagris galeatapallas) in Nigeria. Tropical Agriculture (Trinidad) 66(3): 277-280.

18. Bernacki Z Heller M (2003) Ocean jakoscijajperlicszarych $n$ roznychokresachniensnosci. pr Kom NaukRoln Boil BTN 51: 27-32.

19. Ayorinde KLA (1991) Guinea fowl as protein supplement in Nigeria. World Poultry Science Journal 47 (2): 21-26.
20. Eleroglu H, Yildirim A, Duman M, Okur N (2016) Effects of egg shell colour on the egg characteristics and hatchability of guinea fowl (Numidameleagris). Brazilian Journal of Poultry Science 1516-635X: 061-068.

21. Dudusola I O (2010) Comparative evaluation of internal and external qualities of eggs from quail and guinea fowl Inter. Resource Journal of Plant Science 1: 112-1 15

22. Alkan S, Galic A, Karsli T, Karabag K (2015) Effect of egg weight on egg quality traits in Partridge (Alectorischukar). Journal of Applied Animal Research 43(4): 450-456.

23. Ukwu HO, Ezihe CO, Asaa SK, Anyogo ME (2017) Effect of egg weight on external and internal egg quality traits of Isa Brown egg layer chickens in Nigeria. Journal of Animal Science and Veterinary Medicine 2: 126-132.

24. Chimezie VO, Fayeye TR, Ayorinde KL Adebunmi A (2017) Phenotypic correlation between egg weight and some egg quality traits in three varieties of Japanese quail. Agrosearch 17(1): 44-53.

25. Panda PC (1996) Shape and texture. In text book on egg and poultry technology pp. 57.

26. Cloprakarn K, Salangam I, Janaka K (1998) Laying performance, egg characteristic and egg composition in Thai indigenous hens.

27. Farooq M, Mian MA, Ali m, Durani FR, Asquar A, et al. (2001) Egg traits of Fayomi birds under sub- tropical conditions. Sarad Journal of Agriculture 17: 141-145.

28. Ozcelik M (2002) The phenotypic correlation among some external and internal quality characteristics in Japanese quail eggs. Veterinary Journal, Ankara University 49: 67-72.

29. Kul S, Seker I (2004) Phenotypic correlation between some external and internal egg quality traits in the Japanese quail (Coturnix coturnix japonica) 3(6): 400-405.

30. Abanikannda OTF, Olutogun O, Leigh AO, Ajayi L A (2007) Statistical modeling of egg weight and egg dimensions in commercial layers. International Journal of Poultry Science 6(1): 59-63.

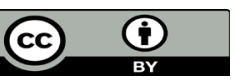

This work is licensed under Creative Commons Attribution 4.0 License

To Submit Your Article Click Here:

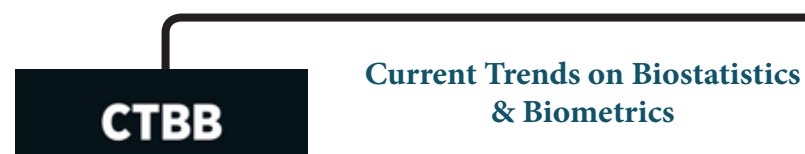

Assets of Publishing with us

- Global archiving of articles

- Immediate, unrestricted online access

- Rigorous Peer Review Process

- Authors Retain Copyrights

- Unique DOI for all articles 